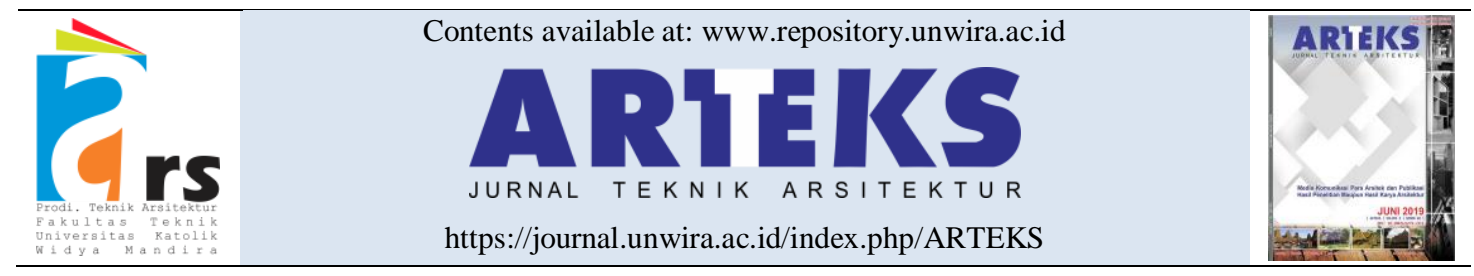

Research paper

doi: $10.30822 /$ arteks.v5i3.563

\title{
Flexible architecture of the 'popsyandu': An appropriate adaptable solution for urban kampung land - use issue
}

\section{Dalhar Susanto*, Widyarko, Nisrina Dewi Salsabila}

\author{
Department of Architecture, Faculty of Engineering, Universitas Indonesia \\ Kampus UI Depok, Jawa Barat, Indonesia
}

\begin{tabular}{|c|c|}
\hline ARTICLE INFO & ABSTRACT \\
\hline $\begin{array}{l}\text { Article history: } \\
\text { Received June } 05,2020 \\
\text { Received in revised form July } 14,2020 \\
\text { Accepted July } 27,2020 \\
\text { Available online December } 01,2020\end{array}$ & $\begin{array}{l}\text { Urban kampung in Indonesia has the characteristics of a high } \\
\text { population density living in a limited amount of land. Residents of } \\
\text { an urban kampung require a space that can be used together to carry } \\
\text { out communal activities. However, the limited amount of land in a } \\
\text { kampung causes these activities to occupy whatever land is available } \\
\text { which often has uncertain ownership status. A team from the }\end{array}$ \\
\hline $\begin{array}{l}\text { *Corresponding author: Dalhar Susanto } \\
\text { Department of Architecture, Faculty of } \\
\text { Engineering, Universitas Indonesia } \\
\text { Email: dalhar3001@yahoo.com }\end{array}$ & $\begin{array}{l}\text { Department of Architecture UI built 'Popsyandu' shelter in } \\
\text { Kampung Palsigunung, Depok, West Java, using the 'flexible } \\
\text { architecture' approach to respond to the needs and issues of the } \\
\text { kampung. Using qualitative methods and data collection through } \\
\text { observation and interview, this paper attempts to discuss the } \\
\text { application offlexible architecture in the design of 'Popsyandu'. The } \\
\text { result shows that the application of 'flexible architecture' approach } \\
\text { is difficult to be comprehended by the residents of the kampung, even } \\
\text { though the designers tried to involve the residents during the design } \\
\text { and construction process. Therefore, the authors conclude that in } \\
\text { adopting a flexible architecture to respond to certain issues, the } \\
\text { designer must consider the capabilities of the user instead of just } \\
\text { following the theories stated beforehand. }\end{array}$ \\
\hline
\end{tabular}

\section{Introduction}

The phenomenon of the urban kampung is created by the uncontrolled growth of the city and inappropriate use of land (Wirasmoyo 2017), and is something that is very commonly found in Indonesia. Urban kampung also known as kampung kota is a settlement that grows in urban areas without infrastructure planning and is not related to the city's economic network (Nursyahbani and Pigawati 2015). It also implies a form of informal settlement. It is in this stead Soefaat, (1997) opined that, urban kampung as part of the city, in the form of housing groups, has a high population, lacks facilities and infrastructure, there is no specific area, can be larger than one sub-district (Departemen Pekerjaan Umum RI 1997); while Jolaoso et al.
(2017) revealed that the emergence of informal housing has been largely viewed as problem and had described it as spontaneous, unplanned and uncoordinated emergent developments, which are often carried out through self-help efforts without necessarily complying with the planning and building regulations or standards (Jolaoso et al. 2017).

Considering that the emergence of an urban kampung is mostly unplanned, an urban kampung generally has inefficient spatial planning. This inefficiency causes both the rise of more abandoned lands (Wirasmoyo 2017), as well as limitation of the amount of proper lands to be used for permanent buildings. Therefore, it is commonly known that one of the main issues within urban kampung is the issue of high population density coupled with a limited amount of land (Lake, Rayawulan, and Arakian 2018). On 
the other hand, the high density of people living in a specific place cannot be separated from the various public activities that need to be carried out. Unfortunately, the limited amount of land raises an obstacle in creating a permanent public space for the urban kampung community, whereas public space is relatively important as it can create cultural and social roots that characterize the kampung area (Wirasmoyo 2017). Therefore, residents of an urban kampung may need to take advantage of any undeveloped lands to be used for communal activities, as the issue of density and land limitations would push creativity for human inhabitants to act and behave (Nugroho 2009).

However, due to the lack of planning in urban kampung, the undeveloped lands being used for communal activities do not have a clear legal ownership status and are often under of government eviction, demolition and displacement. Suffice it is to say that if this were to happen, the space that was once used for communal activities would no longer be used for the public interest (Ardhiansyah, Widyastuti, and Septiari 2019). Consequently, any physical structures that once belonged to the community and accommodated communal activities would be demolished and displaced respectively.

It is against this backdrop that an architectural solution can be made to respond to these issues, in the form of a flexible architecture as a shared space for the community within the urban kampung. Kronenburg (2007) defined flexible architecture as that which "adapts to new uses, responds to change rather than stagnating". Thus, flexible architecture bears the characteristics of adaptability, transformability, movability, and interactivity (Kronenburg 2007). Therefore, the authors hypothesize that the concept and context of flexible and adaptable architecture could be the required solution to the challenges of limitation and temporality of landuse.

To this end, the idea of 'Popsyandu' was born. Located in Kampung Palsigunung, Depok, West Java, Indonesia, the idea was of a shared space to be used together by the residents of the urban kampung. The term posyandu in Indonesian is an abbreviation of "pos pelayanan terpadu" (integrated service post), which functions for basic healthcare services, yet also accommodates other communal activities for the residents. Therefore, the idea of 'Popsyandu' emerge as a response to the needs and limitations of Kampung Palsigunung, where the residents' need for a shared space, as well as, the physical constraints of limited and temporary available pieces of land.

This paper reviews how the 'flexible architecture' approach is applied to the design of 'popsyandu' design, as well as discussing the results obtained from the application of this approach as a shared space in Kampung Palsigunung, which includes reviewing the residents' responses to the architecture. The authors found little to no previous studies discussing the relation of the concept of a flexible architecture to the issue of land availability in an urban kampung. Thus, this paper aims to discuss how the application of the 'flexible architecture' approach can respond to the land-use issue and to discuss whether or not this is an appropriate and applicable response to the main problems faced by urban kampung in Indonesia.

\section{Theoretical studies}

Urban kampung is described as a rural settlement system with the characteristics of a village, but is located in an urban setting, thus having its distinctive features and urban activities (Nursyahbani and Pigawati 2015). A kampung is defined as an enclosed compound in the city that has its characteristics, where the life of a village still appears in a binding social and cultural system (Nugroho 2009). The society in an urban kampung is known to have strong social relations (Harjoko 2009), one of which is characterized by the many interactions between the residents. The large number of people living together on limited land seemed to force the residents in an urban kampung to interact with one another continuously. More so, the limited land available in an urban kampung encourages the residents to utilize the existing land to be able to carry out activities together as a community.

The growth of Indonesia's cities includes a high population growth that is not balanced with the development of facilities, infrastructure, and services, and could potentially create unplanned settlements (Nursyahbani and Pigawati 2015; Wirasmoyo 2017). Therefore, it can be said that one of the main features that characterize informal settlements include unplanned spatial layout (WHO \& UN Habitat 2010; Hutama 2016). This lack of adequate planning in urban kampung may cause the emergence of abandoned lands (Wirasmoyo 2017). These abandoned lands, however, are usually scattered and limited in terms of size. Thus, the limited amount of 
available in an urban kampung makes it relatively hard to create something permanent.

Another issue caused by ineffective planning is the unclarity of land ownerships, which makes it hard to create a permanent structure within an urban kampung area. In general, the ownership of places can be classified into three: public (which can be occupied by any individuals); semi-public; and private, which possess limited access and authority (Hutama 2016). However, this classification might be harder to find in an urban kampung, considering the property of a place, which is usually shared within the community (Hutama 2016). Therefore, the residents as inhabitants of an urban kampung need to be more creative in acting and behaving within the space, mainly by adapting any space in urban kampungs into an adequate public space (Nugroho 2009; Hutama 2016). A public space in an urban kampung is necessary considering it is a forum for the exchange of thoughts and activities, which gives rise to a cultural and social root that characterizes the kampung area (Wirasmoyo 2017). It implies that public space in an urban kampung often requires a physical container or installation to accommodate its various activities (Bawole 2020; Purbadi and Lake 2019). This installation should be located in an area that is easily accessible to all residents. However, the availability of land in an urban kampung often has unclear legal status, where available developments thereon are impermanent, and any structure that is located therewith subject of displacement at any time.

Flexible architecture strongly relates to its ability to adapt. A theory defined flexible architecture as one which adapts to new uses and responds to changes (Kronenburg 2007), while Till and Schneider (2005) described it as one that can adapt to the changing needs of users and is designed for change over its lifetime. It is believed that flexibility is an essential consideration in the design of a building to be socially, economically and environmentally viable and that designing for flexibility means thinking for a longer-term impact (Till and Schneider 2005).

Crowther (1999) stated five main reasons which causes a building to no longer be relevant to its context, namely: locational obsolescence, functional obsolescence, technical obsolescence, physical obsolescence, and fashionable obsolescence. Locational obsolescence is defined as the condition where the building is no longer appropriate or needed in its current location (Crowther 1999), meaning that the building could no longer stand on its initial location.

Considering that the issue found in an urban kampung mainly relates to the limitation and temporality of land, it is highly possible for a locational obsolescence of a building to happen sooner than expected. Obsolescence generally leads to the demolition of an architecture. However, this need of demolition can be avoided or-at least reduced — by making adjustments to the design of the architecture, one of which can be done by applying the approach of a 'flexible architecture' which is believed to be responsive to changes (Crowther 1999; Kronenburg 2007).

Kronenburg (2007) stated four characteristics of flexible architecture, namely: adaptation, transformation, movability, and interaction (Kronenburg 2007). Adaptation refers to how architecture adjusts to different users, functions, and climate changes. Transformation refers to how a building changes itself in terms of shape, form, and/or appearance through alterations of their elements. Movability refers to the ability of a building to be transported from one place to another whereas interaction refers to a building's direct response to a specific user's requirements. These characteristics of a flexible architecture make it possible for it to respond to the inevitability of obsolescence.

In creating an architecture that is 'flexible', several basic considerations need to be addressed. Till \& Schneider (2005) stated three basic things to consider to achieve the flexibility of a building, namely: construction, technological, and use of space. In terms of construction, strategies such as reducing the amount of load-bearing fields and solid partitions could be applied, as well as designing a form and structural configurations that would allow possibilities for future expansions (Till and Schneider 2005). The use of materials and the amount of building components should be minimized to lower the costs and reduce the resource consumption, as well as choosing materials that are more durable and reusable (Pulaski et al. 2004). On the other side, the technological aspects and use of space of a building should accommodate adaptability (Prasetyo, Tobing, and Budiyuwono 2018; Sanjaya and Tobing 2019). The technology being used should be accessible and adaptive, while the use of space should be of varieties not limited to one purpose and the space should be accessible 
through more than just one way (Till and Schneider 2005).

However, considering that the approach of 'flexible architecture' on the theories stated earlier was written through the perspective of a designer, it may not be applicable in every urban kampung. Considering that the economic condition and level of education of a resident of urban kampung is on average lower than those of the urban area, certain methods of construction and technologies may be considered too complicated: thus, making the idea of a 'flexible architecture' hard to be comprehended by the targeted users of the architecture.

\section{Method}

This paper discusses a case study of a small wooden shelter named 'Popsyandu', a shelter for communal activities located in Kampung Palsigunung, Depok, West Java. According to the designer, a team from the Department of Architecture Universitas Indonesia (DA-UI), this shelter was designed using the concept of flexible architecture stated by Kronenburg (2007). The study uses qualitative research methods, which involves an interpretive and naturalistic approach to its subject matter. These approaches meant that researchers tend to study things in their natural settings: considering things as they are, not manipulating the environment (London and Ostwald 2004). The problems found in these methods are that the research tends to be more open-ended and the results' interpretations are possibly biased-influenced by the researcher's perspective. That is why qualitative research needs to involves reporting multiple viewpoints, distinguishing the many factors involved in a situation (Groat and Wang 2013).

To maximize objectivity during the qualitative research, this study took in two different methods of primary data collection, namely: observations and interviews. The study used multiple data collection methods because it is believed to complement each other to accommodate a better and more comprehensive understanding of the research problem, while the weaknesses of each method individually are more likely to be avoided (Groat and Wang 2013).

Observations were conducted during the shelter's construction phase and were used to get a better understanding of the concept-design- implementation through the designer's perspective. However, the observation was done by observers who was also a part of the design team: thus, having the potential of being biased and less objective. Therefore, data collection through the interview was done to minimize this bias and increase objectivity. The interview was conducted to four people who were involved in the construction process, namely: one construction worker and three community leaders of Kampung Palsigunung who also resides nearby to the location of the 'Popsyandu'.

\section{Result and discussion}

\section{'Popsyandu' in Urban Kampung Palsigunung, Depok}

Kampung Palsigunung is an urban kampung located in the City of Depok, West Java, Indonesia. This kampung is characterized by dense and dynamic demographic and spatial conditions. The residents and communal activities are very diverse: from children who need space to play and learn; fathers with activities like hanging out, playing chess or carrom; to mothers with activities like Quranic recitation, social gathering, and even carrying posyandu activities. However, just like the general urban kampung in Indonesia, Kampung Palsigunung is also faced with land limitations in terms of amount or size of land available, and the unclarity of land ownerships. These issues made it difficult for the residents of the kampung to build a type of structure or shelter which could facilitate communal activities.

One of the many Communal activities often found in this kampung is related to basic healthcare, specifically posyandu activities. Posyandu (Pos Pelayanan Terpadu) is defined as a form of Community-Based Health Efforts (UKBM) which is managed from, by, for and with the community, to empower the community and provide facilities to the community in obtaining basic health services especially for mothers and babies (Kementerian Kesehatan RI 2011; 2012; Departemen Kesehatan RI 2006).

Although the term posyandu refers to a healthcare system rather than merely a 'pos' (station) it is undeniable that a proper place or shelter is required to accommodate the activities. The activities generally can be held at the homes of residents, community centers, kiosks in the market, or specific places that have been made 
based on community self-help (Departemen Kesehatan RI 2006). The interview conducted shows that Kampung Palsigunung had three posyandu used by all residents of the kampungtwo of which are located in people's homes.

Thus, the idea of 'Popsyandu' emerged as a response to the issue found in Kampung Palsigunung. 'Popsyandu' shelter was a community service project carried out by a team of lecturers and students from the Department of Architecture, Universitas Indonesia (DA-UI). The name 'popsyandu' is taken from a combination of two words, namely: 'pop' which refers to the construction method used in this shelter that is easy to assemble and to disassemble and 'posyand $u$ ' which refers to one of the communal activities often found in the Kampung Palsigunung that needs to be contained by an installation or shelter. This project was built on a $3 \times 3 \mathrm{~m}^{2}$ land borrowed from a resident. In consideration of its continuity, the 'Popsyandu' shelter must be as cheap as possible in and involve citizens in their assembly and maintenance as much as possible.

The design process 'Popsyandu' involves the team from DA-UI and residents from Kampung Palsigunung. The spatial layout of 'Popsyandu' shelter was designed to have a feeling of openness through minimizing the number of boundaries. On the lower floor of the shelter, the space is made entirely open without borders, whereas on the upper floor is bounded by a railing that has a low height or with a transparent partition.

The fabrication process started in the FTUI Department of Architecture's wood workshop, this shelter was assembled at the UI campus location and remained there for approximately one month. After that, the 'Popsyandu' shelter was disassembled into separate components and transported to the designated spot in Kampung Palsigunung (figure 1). At the final location, the components were reassembled to become a wooden shelter building, which is intact and stands up to now.

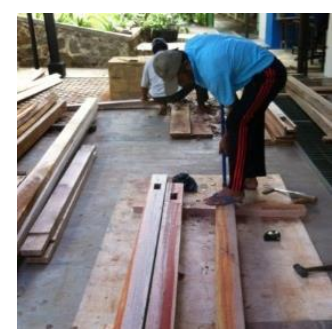

1. Components fabrication in Universitas Indonesia (UI)

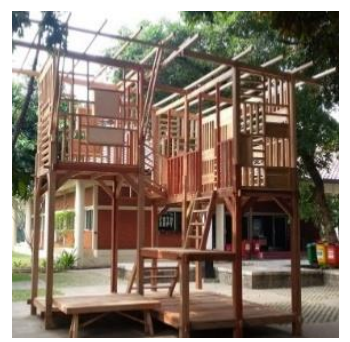

3. Assembled shelter in Universias Indonesia (UI), tested for one month

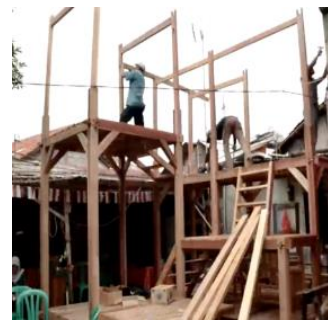

5. Reassembled in the final location in Kampung Palsigunung

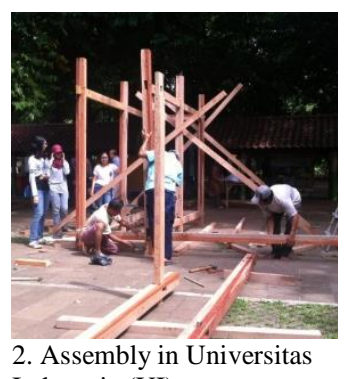
Indonesia (UI)

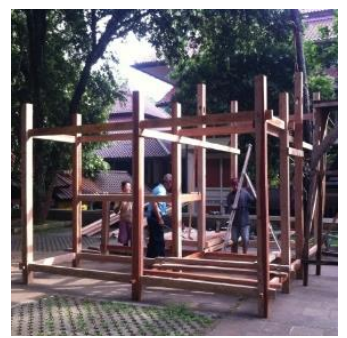

4. Shelter disassembled to be transported

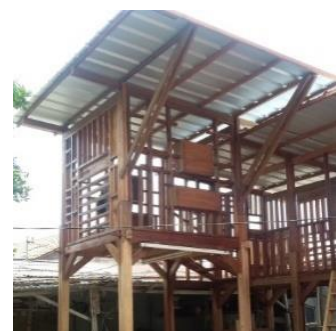

6. Assembled shelter in Kampung Palsigunung, still used to this day

Figure 1. Design and construction process of 'popsyandu' shelter

The 'popsyandu' shelter uses locally available materials and technology. The main material used in this shelter was reclaimed lumber gathered from demolished buildings from around the greater Jakarta area. The designer chose the reclaimed lumber since this material was cheaper than virgin lumber, and the previous study also proves that used woods had better material properties than newly produced lumber (Susanto and Widyarko 2017). The only non-wood parts were the roof material; corrugated sheet metal was chosen as the material, consisting of 2 metals sheets installed using a screw. 


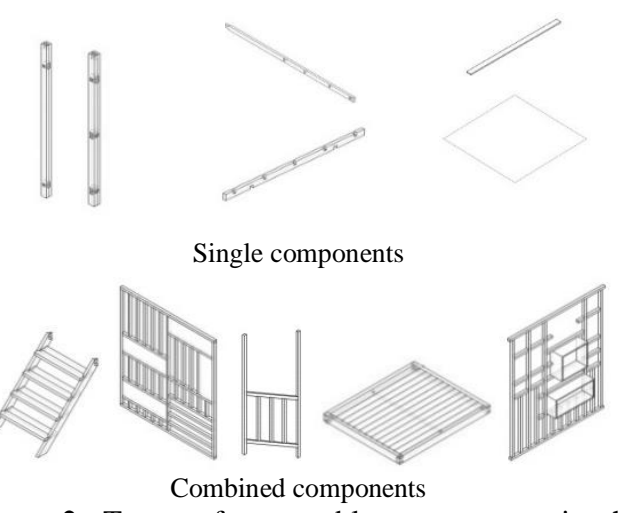

Figure 2. Types of removable components in the design of 'popsyandu' shelter

Source: Documentation from DA-UI, 2017

The designer uses a term of demountable construction system, which allows buildings to be assembled and disassembled repeatedly. Figure 2 shows the types of components used in the construction of the shelter. Furthermore, this system allows buildings to be transported in a separate state and easily reassembled at a new location. This system makes it possible for the shelter to be moved to other locations easily by using a small lorry. With the demountable construction technique, equipped with the use of non-permanent joints (figure 3) and the use of simple and local construction systems, the Popsyandu shelter can be assembled easily and quickly.

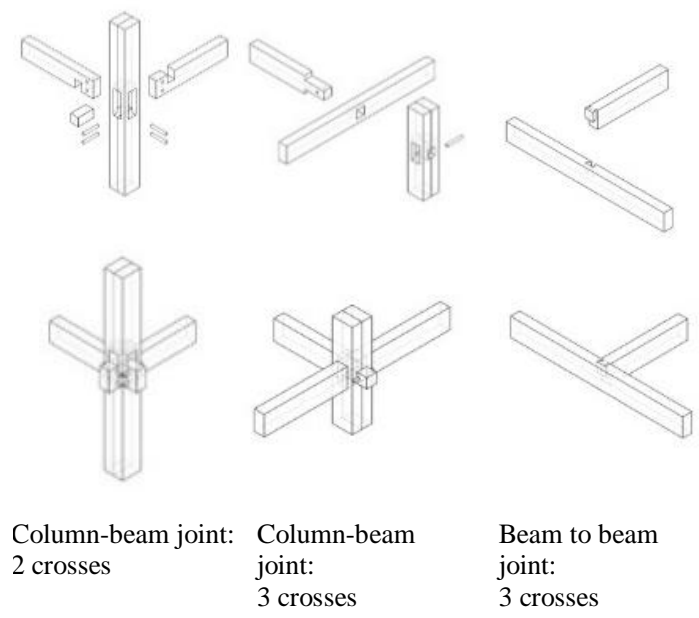

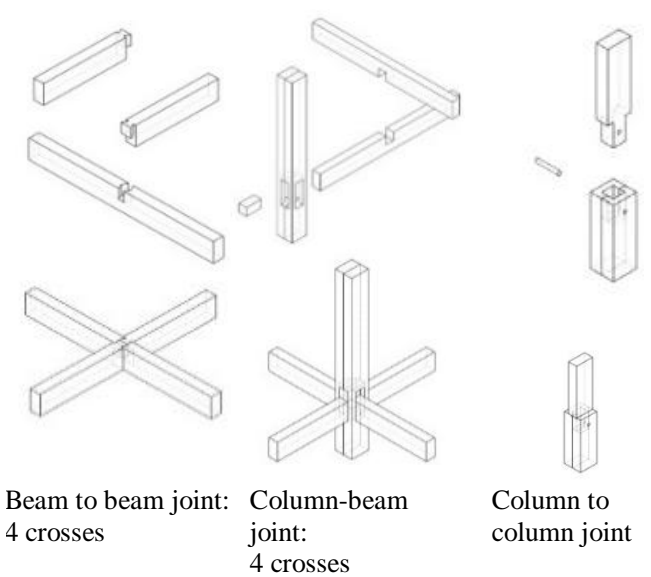

Figure 3. Types of non-permanent joints in the design of 'popsyandu' shelter

Source: Documentation from DA-UI, 2017

The assembly process consists of 60 steps (figure 4), involves 3-4 people, and takes about 23 days to complete. The assembly process involves connecting components according to the type, function and position of each into a part or to the building as a whole. In short, the use of the knock-down method with simple techniques in the construction of 'popsyandu' shelter was chosen so that the building could be easily assembled and disassembled to fit the needs of the residents, as well as simpler maintenance to be carried out by the users of the space.

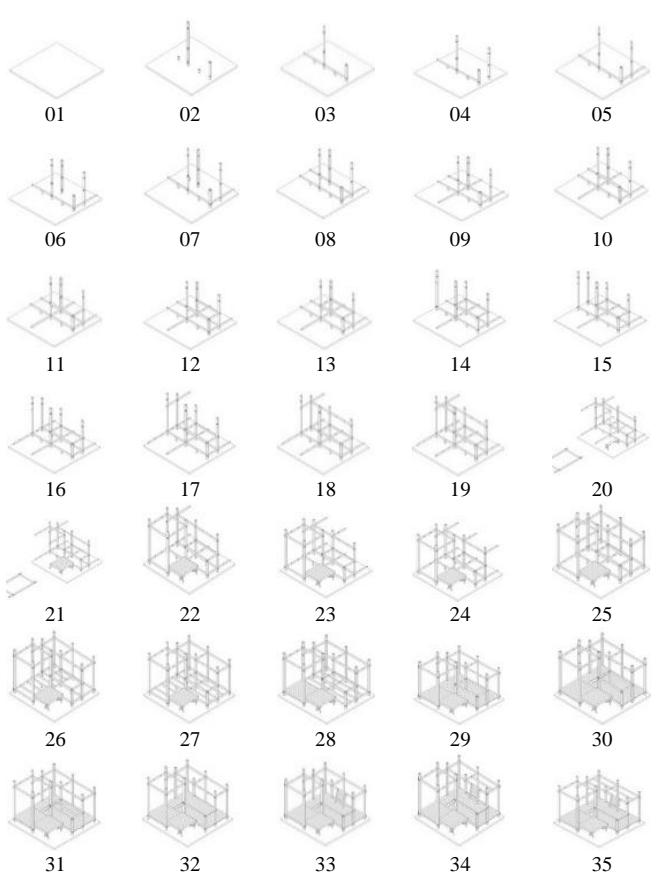




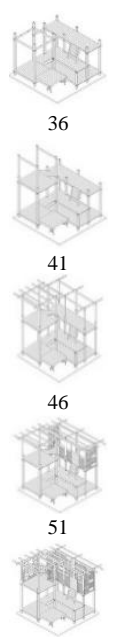

56

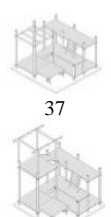

42
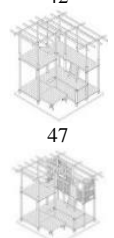

52

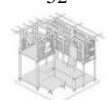

57

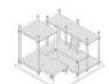

38

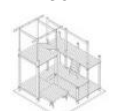

43

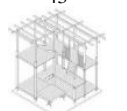

48

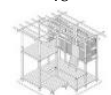

53

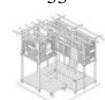

58

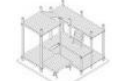

39

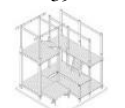

44

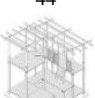

49

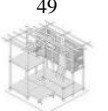

54

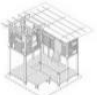

59

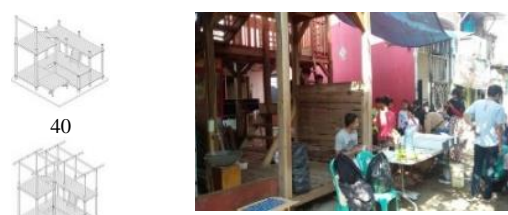

as a training ground for residents

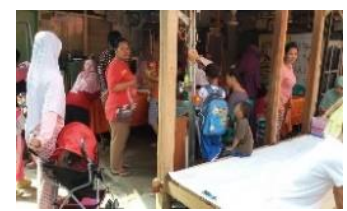

as a place to carry out posyandu activities

Figure 5. Activities in popsyandu by the residents of Kampung Palsigunung, Depok

In the context of urban kampung, in which land availability (a limited amount of available land and unclear land ownership status) is one of the main issues faced, locational obsolescence is more likely to occur compared to other places that do not face the same issue. Thus, the life span of a building in an urban kampung tends to be shorter than expected and subject of perpetual threat of demolition and displacement

This issue was also found in Kampung Palsigunung, Depok. Based on the interview conducted with the residents of the kampung, there had been a transfer of a public facility from one location to another for reasons related to land ownership. The land that was used to accommodate the residents' communal needs became unavailable; thus, subject of distruption and translocation of habitation and activities. Therefore, it can be said that locational obsolescence has occurred in Kampung Palsigunung.

However, responding to locational obsolescence may be simpler than suspected. Considering that the issue only relates to its whereabouts, an action as simple as moving a building to a more appropriate location can be done to avoid demolition due to locational obsolescence. A building's ability to be transported or moved to another site has also been discussed by Kronenburg (2007) as being one of the four essential characteristics of flexible architecture, also known as movability. Movable buildings are defined as those specifically designed to be able to move from place to place so that they can fulfill their function better (Kronenburg 2007).

According to Kronenburg (2007), one approach to designing a movable building is using the demountable method, in which a building can be transported in parts or components to be assembled on another location. Based on the observation, it was seen that the shelter was dismantled into many parts and components. These parts were transported from Universitas 
Indonesia to be reconstructed in Kampung Palsigunung using several lorry trips. Thus, it can be said that this demountable method was used in the construction of 'Popsyandu' shelter.

The demountable method used in 'Popsyandu' shelter is also supported by the use of nonpermanent joints, also known as reversible connections. Reversible connections are defined as the kind of joints that tolerate repeated assembly and disassembly (Jensen and Sommer 2018). In 'Popsyandu' shelter, the use of nonpermanent joints allows for more flexibility and ease of maintenance, making it simpler for the building to be assembled and disassembled; thus, taking less time to be transported and constructed.

The design of 'Popsyandu' shelter also considers of the aspects stated by Till and Schneider (2005), as mentioned earlier. First, in consideration the construction, the shelter design maximizes the use of wood bars to be constructed as frames. Several types of panels were also used but kept to a minimum amount. This leads to the lightness of building weight, making it easier for transporting as well as assembling. This shelter was also built using an elevated building construction system (figure 6) so that the structure can stand easily on an existing surface/site; thus, the assembly and disassembly process can be easier, supporting the movability of the building.

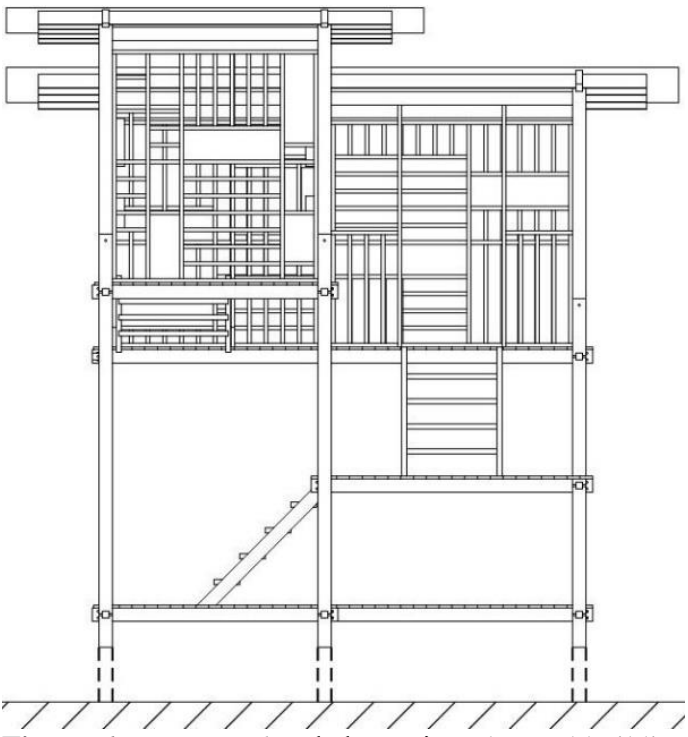

Figure 6. 'Popsyandu' shelter using elevated building construction system

Source: Documentation from DA-UI, 2017

Figure 7 further shows that this shelter minimizes the number of boundaries, thus creating the feeling of a space with an open plan. The lower level of the shelter has no boundaries, thus, the use of space inside the shelter can be extended to the areas outside of the shelter; whereas the upper levels of the shelter needed to have boundaries for safety reasons (figure 7a). The shelter was designed with the concept of split-level (figure $7 \mathrm{~b}$ ) to give continuity to the space. This split-level solution also leads to the shelter having various spaces with diverse spatial patterns. These findings show that the design of 'Popsyandu' shelter takes in consideration of the use of space by minimizing boundaries and maximizing continuity which supports the flexibility of the space. The information extracted from the interview shows that as an open building, the residents of Kampung Palsigunung views 'Popsyandu' as an inclusive space, memorable to invite and accept anyone, become a focal point for communal activities and connect all residents.

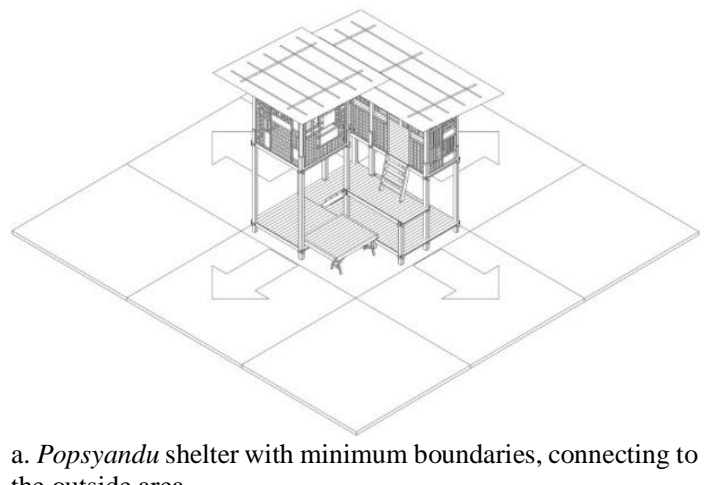
the outside area

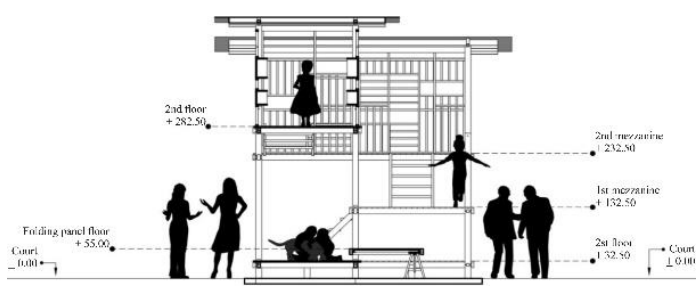

b. Popsyandu section drawing showing the split-level concept of the design

Figure 7. The flexibility of the use of space through open-plan, and split-level design

Source: Documentation from DA-UI, 2017

The design of the shelter attempts to use locally available materials, technology, and uses the type of connection commonly found in everyday construction practices. The tools involved were simple (such as saws, shavers, and hammers) mechanical and manual ones. These attempts shows that technological aspects was in 
fact being considered by the designers. The residents of Kampung Palsigunung was also involved, both in the designing and reconstructing the process of the shelter, as an attempt to get the residents to understand how to assemble and disassemble the shelter so it can be moved and reassembled elsewhere. By using local and common technology, the maintenance was expected to be quite simple and possible to be done by the residents themselves, without the help of experts.

However, even though the shelter was designed to be as simple as possible-coupled with the designers' attempt to teach the residents - the interview conducted with the residents of Kampung Palsigunung shows that the many steps of construction makes them feel like they might have difficulty in disassembling and reassembling the shelter themselves, if ever needed. This finding shows that the theories stated earlier regarding considerations of a flexible architecture may not always be applicable in every context. Thus, the design needs to also consider the ability of the intended users of the space to maximize its potential for flexibility.

\section{Conclusion}

Considering the main issue found in an urban kampung is of land availability - both relating to size and number, as well as relating to land ownership - the possibility of locational obsolescence happening sooner than expected becomes something to look after. This issue had been found in Kampung Palsigunung, Depok, where a public facility had to be moved from one location to another for reasons related to land ownership, meaning that the previous location had become unavailable and therefore, considered obsolete. However, since the issue only refers to its location, a response as simple as moving the building - physically and functionally - to another location can be appropriate. This is where the flexibility-more specifically, the movability - of an architecture plays a role. The 'popsyandu' shelter was designed using the 'flexible architecture' approach to respond to the land-use issue found in Kampung Palsigunuung. The design of the shelter takes in consideration of the construction methods, technological aspects, as well as the use of space: all aspects were designed to be as simple and flexible as possible to be able to accommodate the needs of the residents. However, the interview conducted with the residents shows that the residents might have difficulty disassembling and reassembling the shelter themselves, if ever needed: thus, implying that the 'flexible architecture' approach was not easy to comprehend. These findings suggest that in designing a flexible architecture to respond to a spesific issue, the designers should consider the conditions and ability of the intended users of the space, more than just the aspects stated in the theories beforehand.

\section{References}

Ardhiansyah, Nino, Dhyah Ayu Retno Widyastuti, and Elisabet Dita Septiari. 2019. 'Perubahan Tata Guna Lahan Kampung Prawirotaman Kota Yogyakarta Sebagai Dampak Keberadaan Kawasan Komersial'. ARTEKS: Jurnal Teknik Arsitektur 3 (2): 149-58.

https://doi.org/10.30822/arteks.v3i2.66.

Bawole, Paulus. 2020. 'Pengembangan Kampung Kota Sebagai Salah Satu Alternatif Tujuan Wisata Minat Khusus'. ARTEKS: Jurnal Teknik Arsitektur 5 (1): 115-26. https://doi.org/10.30822/arteks.v5i1.362.

Crowther, Philip. 1999. 'Design for Disassembly : An Architectural Strategy'. In Design for Disassembly: An Architectural Strategy. Queensland University of Technology Winter Colloquium. https://eprints.qut.edu.au/49696/.

Departemen Kesehatan RI. 2006. Pedoman Umum Pengelolaan Posyandu. Jakarta: Departemen Kesehatan RI bekerja sama dengan Kelompok Kerja Operasional. http://dp2m.umm.ac.id/files/file/bukupedoman-umum-pengelolaan-posyandu1.pdf.

Departemen Pekerjaan Umum RI. 1997. Kamus Tata Ruang. Edited by Soefaat. 1st ed. Jakarta: Direktorat Jenderal Cipta Larya, Departemen Pekerjaan Umum, Ikatan Ahli Perencanaan Indonesia.

Groat, Linda N., and David Wang. 2013. Architectural Research Methods. 2nd ed. New York: John Wiley \& Sons, Inc.

Harjoko, Triatno Yudo. 2009. Urban Kampung: Its Genesis and Transformation into Metropolis, with Particular Reference to 
Penggilingan in Jakarta. Saarbrucken: VDM Verlag Dr. Müller.

Hutama, Irsyad Adhi Waskita. 2016. 'Exploring the Sense of Place of an Urban Through the Daily Activities, Configuration of Space and Dweller's Perception: Case Study of Kampung Code, Yogyakarta'. University of Twente.

https://webapps.itc.utwente.n1/librarywww/pa pers_2016/msc/upm/hutama.pdf.

Jensen, Kasper Guldager, and John Sommer. 2018. Building a Circular Future. 3rd ed. GXN Innovation. https://gxn.3xn.com/wpcontent/uploads/sites/4/2018/09/Building-aCircular-Future_3rd-

Edition_Compressed_V2-1.pdf.

Jolaoso, B. Adekoyejo, Olatunde Arayela, Abraham A. Taiwo, and Clement O. Folorunso. 2017. 'Emergence of Informal Housing: Implications for Development of Low-Cost Housing Delivery Strategies in Abeokuta, Nigeri'. International Journal of Innovative Research \& Development 6 (3): 191-98.

http://www.internationaljournalcorner.com/in dex.php/ijird_ojs/article/view/136818/95941.

Kementerian Kesehatan Republik Indonesia. 2012. Buku Pegangan Kader POSYANDU. Jakarta: Kementerian Kesehatan Republik Indonesia Pusat Promosi Keshatan. https://www.kemkes.go.id/resources/downloa d/promosi-kesehatan/buku-sakuposyandu.pdf.

Kementerian Kesehatan RI. 2011. Pedoman Umum Pengelolaan Posyandu. Jakarta: Kementerian Kesehatan RI.

Kronenburg, Robert. 2007. Flexible: Architecture That Responds to Change. 1st ed. London: Laurence King.

Lake, Reginaldo Christophori, Robertus Mas Rayawulan, and Donatus Arakian. 2018. “"Keberlanjutan Dan Perubahan" Orientasi Permukiman Kajian Fenomena Permukiman Airmata Di Bantaran Kali Kaca Kota Kupang'. In Seminar Nasional Riset Dan Teknologi Terapan (RITEKTRA 8), Prosiding, TA-28-TA-36. Makassar: Fakultas Teknik Unika. Atma Jaya Jakarta. http://www.uajm.ac.id/files/journals/prosidin g/Prosiding Ritektra 8.pdf.

London, Kerry, and Michael Ostwald. 2004. 'Architectural Research Methods'. Nexus
Network Journal 6 (1): 51-53. https://doi.org/10.1007/s00004-004-0006-7.

Nugroho, Agung Cahyo. 2009. 'Kampung Kota Sebagai Sebuah Titik Tolak Dalam Membentuk Urbanitas Dan Ruang Kota Berkelanjutan'. Jurnal Rekayasa 13 (3): 20918. http://ftsipil.unila.ac.id/ejournals/index.php/jrekayas a/article/viewFile/20/pdf.

Nursyahbani, Raisya, and Bitta Pigawati. 2015. 'Kajian Karakteristik Kawasan Pemukiman Kumh Di Kampung Kota (Studi Kasus: Kampung Gandekan Semarang)'. Teknik PWK (PERENCANAAN WILAYAH KOTA) (E-JOURNAL) 4 (2): 267-81. https://ejournal3.undip.ac.id/index.php/pwk/a rticle/view/8463/8228.

Prasetyo, Lucky, Rumiati Rosaline Tobing, and Hartanto Budiyuwono. 2018. 'Konsep Ekologis Dan Budaya Pada Perancangan Hunian Paska Bencana Di Yogyakarta'. ARTEKS: Jurnal Teknik Arsitektur 2 (2): 125-36. https://doi.org/10.30822/arteks.v2i1.46.

Pulaski, Michael, Christopher Hewitt, Michael Hormat, and Brandley Guy. 2004. 'Design for Deconstruction'. Modern Steel Construction 44 (6).

Purbadi, Yohanes Djarot, and Reginaldo Christophori Lake. 2019. 'Konsep KampungWisata Sejahtera, Kreatif, Cerdas Dan Lestari Berkelanjutan'. EMARA: Indonesian Journal of Architecture 5 (1): 12-23. https://doi.org/10.29080/eija.v5i1.641.

Sanjaya, Wisnu A., and Rumiati Rosaline Tobing. 2019. 'Rumah Susun Modular Dengan Pemanfaatan Papan Prafabrikasi Cross Laminated Timber Panel (CLT), Kasus Studi: Rumah Susun Siwalankerto, Surabaya'. ARTEKS: Jurnal Teknik Arsitektur 3 (2): 199-214 https://doi.org/10.30822/arteks.v3i2.70.

Susanto, Dalhar, and Widyarko Widyarko. 2017. 'Sustainable Material: Used Wood As Building Material'. INSIST 2 (1): 14. https://doi.org/10.23960/ins.v2i1.26.

Till, Jeremy, and Tatjana Schneider. 2005. 'Flexible Housing: The Means to the End'. Arq: Architectural Research Quarterly 9 (3- 
4): https://doi.org/10.1017/S1359135505000345.

WHO \& UN Habitat. 2010. 'Hidden Cities: Unmasking and Overcoming Health Inequities in Urban Settings'. Switzerland.

Wirasmoyo, Wiliarto. 2017. 'Optimalisasi Lahan Terlantar Menjadi Ruang Publik Di Kampung
Kota; Studi Kasus: Lahan Terlantar Kampung Badran RW. 09, Yogyakarta'. Jurnal Arsitektur KOMPOSISI 11 (5): 217. https://doi.org/10.24002/jars.v11i5.1295. 
ARTEKS : Jurnal Teknik Arsitektur, Volume 5, Issue 3, December 2020

pISSN 2541-0598; eISSN 2541-1217 